\title{
A comparison of lignin-degrading enzyme activities in forest floor layers across a global climatic gradient
}

\author{
Kazumichi Fujii ${ }^{1,}$, Yuji Nakada ${ }^{2}$, Kiwamu Umezawa $^{3}$, Makoto Yoshida ${ }^{2}$, Makoto Shibata ${ }^{4}$, \\ Chie Hayakawa $^{5}$, Yoshiyuki Inagaki ${ }^{1}$, Takashi Kosaki ${ }^{6}$, Ryan Hangs ${ }^{7}$ \\ 1 Forestry and Forest Products Research Institute, Tsukuba 305-8687, Japan \\ 2 Institute of Agriculture, Tokyo University of Agriculture and Technology, Tokyo 183-8509, Japan \\ 3 Faculty of Agriculture, Kindai University, Nara 631-8505, Japan \\ 4 Niigata Agro-Food University, Niigata 959-2702, Japan \\ 5 Faculty of Agriculture, Utsunomiya University, Utsunomiya 321-8505, Japan \\ 6 Faculty of International Communication, Aichi University, Nagoya 453-8777, Japan \\ 7 Department of Soil Science, Saskatchewan University, Saskatchewan S7N 5A8, Canada
}

A RTICLE I NFO

Article history:

Received November 26, 2019

Revised February 27, 2020

Accepted May 11, 2020

Keywords:

Acidification

Ligninolysis

Litter decomposition

Manganese

White-rot fungi

\begin{abstract}
A B S T R A C T
Rapid litter turnover in tropical forests and during summer seasons might be due to increases in ligninolytic enzyme activities during warmer periods. We compared ligninolytic enzyme activity [lignin peroxidase (LiP), manganese peroxidase (MnP), and laccase (Lac)] in the organic layers of forest soils across a global climate gradient. As expected, MnP activities in fresh litter layers increased with increasing air temperature. Litter Mn/lignin ratios correlate positively with $\mathrm{MnP}$ activity and more rapid litter turnover in warmer climates. In contrast, LiP and Lac activities are regulated by site-specific conditions. Lac activity is commonly observed in less acidic fresh litter layers, while LiP activity localizes in acidified and lignin-rich deeper organic layers. The widespread occurrence of MnP and an increase in MnP activities in warmer climates support efficient lignin degradation in the tropics and during summer seasons. High $\mathrm{Mn} /$ lignin ratios in fresh litter could be an indicator of lignin degradability by MnPproducing fungi across global climate gradients.
\end{abstract}

(c) Higher Education Press 2020

\section{Introduction}

Lignin degradation is a rate-limiting step in litter decomposition in forest ecosystems (Berg et al., 2007; Osono, 2007). Lignin, as well as cellulose and hemicelluloses, is a major constituent of plants. The complex aromatic macromolecular structure of lignin differs from cellulose and is resistant to microbial attack (Kirk, 1984). Also, lignin degradation requires oxidative reactions by a complex set of ligninolytic enzymes (Ten Have and Teunissen, 2001). Despite chemical and

\footnotetext{
* Corresponding author

E-mail address: fjkazumichi@gmail.com (K. Fujii)
}

biological recalcitrance, rapid litter turnover in warmer temperate and tropical forests is supported by efficient lignin degradation. Understanding of enzymes involved in lignin oxidation in the forest soils and under laboratory conditions has gradually improved (Kellner et al., 2014). However, the linkage between ligninolytic enzyme activity and litter turnover remains unclear at global and local scales.

White-rot basidiomycete fungi decompose lignin effectively by secreting enzymes (Hofrichter, 2002). Lignin (LiP) and manganese peroxidases $(\mathrm{MnP})$ are efficient ligninolytic enzymes (Leonowics et al., 2001), and a variety of the other ligninolytic enzymes [e.g., laccase (Lac), versatile peroxidase, aromatic peroxidase, and chloroperoxidase] are also reported (Wong, 2009). The presence of MnP has been confirmed in 
organic layers, and woody debris in some temperate forests (Yoshida et al., 2011; Kellner et al., 2014). Still, patterns of ligninolytic enzyme activity remain unreported among forests that differ in climate, vegetation, and soil type.

Climate, vegetation, and soil types likely affect the activity of $\mathrm{LiP}, \mathrm{MnP}$, and Lac in response to soil properties $\mathrm{pH}, \mathrm{Mn}$ levels), and microbial communities, lignin, $\mathrm{Mn}$, and nitrogen (N) concentration in fresh litter (Criquet et al., 2000; Osono, 2007). More rapid litter turnover in warmer climates, such as in tropical forests during summer seasons requires increased enzymatic activity for efficient lignin degradation. For example, greater annual precipitation (leaching) leads to a decrease in soil pH (Slessarev et al., 2016). Lignin degradation by specific fungi may increase by production of LiP, the ligninolytic enzyme with the lowest $\mathrm{pH}$ optimum (Fuji et al., 2013a). Also, MnP activities could be stimulated by high litter Mn levels (Bonnarme and Jeffries, 1990; Berg et al., 2007).

Variation in litter and soil properties may affect dominant ligninolytic enzymes and litter turnover (Tuomela et al., 2002; Berg et al., 2007). Litter Mn may promote litter degradation by stimulating MnP activity. However, relationships between MnP activities and litter turnover has rarely been confirmed under field conditions.

In this study, our objectives are (1) to describe general patterns of ligninolytic enzyme activity across a global climatic gradient, and (2) to examine relations between ligninolytic enzyme activities, litter decomposition rates and chemical and biological properties of the organic layers and soils. Studies targeted parameters such as litter $\mathrm{pH}$, carbon $(\mathrm{C}) / \mathrm{N}$ ratio, lignin, lignin/ $\mathrm{N}$ ratio, $\mathrm{Mn}, \mathrm{Mn} /$ lignin ratio, and fungal activity. We compared ligninolytic enzyme activities from 16 sites, including boreal forests (Canada), temperate forests (Japan, USA), and tropical forests (Indonesia, Cameroon). We also confirmed the identity of ligninolytic enzymes and their sources at a molecular level and analyzed their importance for forest litter turnover using our data along with data sets from previous works.

\section{Materials and methods}

\subsection{Sampling of organic layers}

Organic layer samples were collected from 16 upland sites from August 2008 in Canada and in August 2011 in Japan, USA, Indonesia, and Cameroon (Table 1). The fresh litter and humified layers, if any, were collected separately from each location in three replicates. Litter (L), fermented (F), humified $(\mathrm{H})$, and a mixture of $\mathrm{F}$ and $\mathrm{H}$ layers $\mathrm{FH}(\mathrm{FH})$ layers collected correspond to $\mathrm{Oi}, \mathrm{Oe}, \mathrm{Oa}$, and Oea horizons in soil taxonomy, respectively (Soil survey staff, 2014). Samples were collected from Canada (Sites 1-5), USA (Site 6), Japan (Sites 7-11), Indonesia (Sites 12, 13, 14), and Cameroon (Sites 15, 16) (Table 1). Sites were selected to reflect the variability in lignin and soil $\mathrm{pH}$ in boreal, temperate, tropical forests. Boreal forests included aspen forests on less acidic alfisols and coniferous forests on acidic inceptisol and spodosol. Tempe- rate forests included beech forests on less acidic Andisol, beech or oak forests on acidic inceptisol and spodosol, and coniferous forests on the Andisol. Tropical forests included non-N-fixing and $\mathrm{N}$-fixing tree species that differ in lignin and $\mathrm{N}$ concentrations and two soil types, ultisol and oxisol, that differ in pH (Fujii et al., 2018).

\subsection{Chemical properties of organic horizon samples}

Litterfall was collected from three forest plots $(20 \mathrm{~m} \times 20 \mathrm{~m})$ per site using circular litter traps $(60 \mathrm{~cm}$ diameter) in five replicates. The organic layers were collected from three $30 \mathrm{~cm}$ $\times 30 \mathrm{~cm}$ quadrants per site. Litterfall and organic layer samples were oven-dried at $70^{\circ} \mathrm{C}$ for $48 \mathrm{~h}$, weighed, and milled. $\mathrm{pH}$ values of organic layers $(\mathrm{L}$ and $\mathrm{FH}$, or $\mathrm{L}, \mathrm{F}$, and $\mathrm{H}$, if any) were measured using a milled litter-to-solution (water) ratio of 1:20 (w/v). Klason lignin concentrations in fresh litter and $\mathrm{FH}$ layer samples were determined by digestion with sulfuric acid (Allen et al., 1974). Mn concentrations in fresh litter and $\mathrm{FH}$ layer samples were determined using inductively coupled plasma atomic emission spectrometry (ICP-AES, SPS1500, Seiko Instruments Inc.) after nitric-sulfuric acid wet digestion. The $\mathrm{C}$ and $\mathrm{N}$ concentrations were determined using a $\mathrm{CN}$ analyzer (Vario Max CN, Elementar Analysensystem $\mathrm{GmbH}$ ). Organic layer $\mathrm{C}$ was assumed to reach steady-state, and decomposition rate factors $\left(\mathrm{yr}^{-1}\right)$ of $\mathrm{C}$ in the organic layer $(\mathrm{L}+\mathrm{FH})$ was calculated by dividing litterfall $\mathrm{C}$ input ( $\left.\mathrm{Mg} \mathrm{C} \mathrm{ha}^{-1} \mathrm{yr}^{-1}\right)$ by organic layer $\mathrm{C}\left(\mathrm{Mg} \mathrm{C}^{-1}\right.$ ) (Olson, 1963). These litter degradation rate factors are not precise compared to factors measured using in situ litterbag tests, yet we confirmed that litter decomposition rate factors (1.6) are comparable to factors obtained using litter bag tests in a tropical forest (1.5-2.0; Fujii and Hayakawa, 2020). Lignin $(\%) / \mathrm{N}(\%)$ ratios were calculated and used as an indicator of litter recalcitrance (Aerts, 1997). We also calculated Mn per lignin [Mn (\%)/lignin (\%) ratios] and defined results as indicators of litter Mn availability for ligninolysis.

\subsection{Chemical and biological properties of surface soil samples}

Soil samples $(0-5 \mathrm{~cm}$; A horizon) under the organic layers were air-dried and crushed to pass through a 2-mm sieve before analysis. Soil $\mathrm{pH}$ was measured using soil to solution (water or $1 \mathrm{M} \mathrm{KCl}$ ) ratios of 1:5 after shaking for $1 \mathrm{~h}$. Soil $\mathrm{C}$ concentrations were determined using a $\mathrm{CN}$ analyzer. Clay content was measured using a pipette method.

To approximate fungal activity, the relative contribution of fungi to glucose-induced respiration in soil ( $0-5 \mathrm{~cm}$ depth) was measured by selective inhibition (Anderson and Domsch, 1973; Joergensen and Wichern, 2008). Field-moist soil samples were amended with ${ }^{14} \mathrm{C}$-labeled glucose with and without cycloheximide (fungal respiratory inhibitor) (equivalent to 8-24 $\mathrm{mg}$ cycloheximide $\mathrm{g}^{-1}$ soil, respectively) and incubated at $22^{\circ} \mathrm{C}$ for $24 \mathrm{~h} .{ }^{14} \mathrm{C}-\mathrm{CO}_{2}$ was collected in $1 \mathrm{M}$ $\mathrm{NaOH}$ solution and measured using liquid scintillation counting (Aloka, LSC-3050). The percent contribution of fungi to 


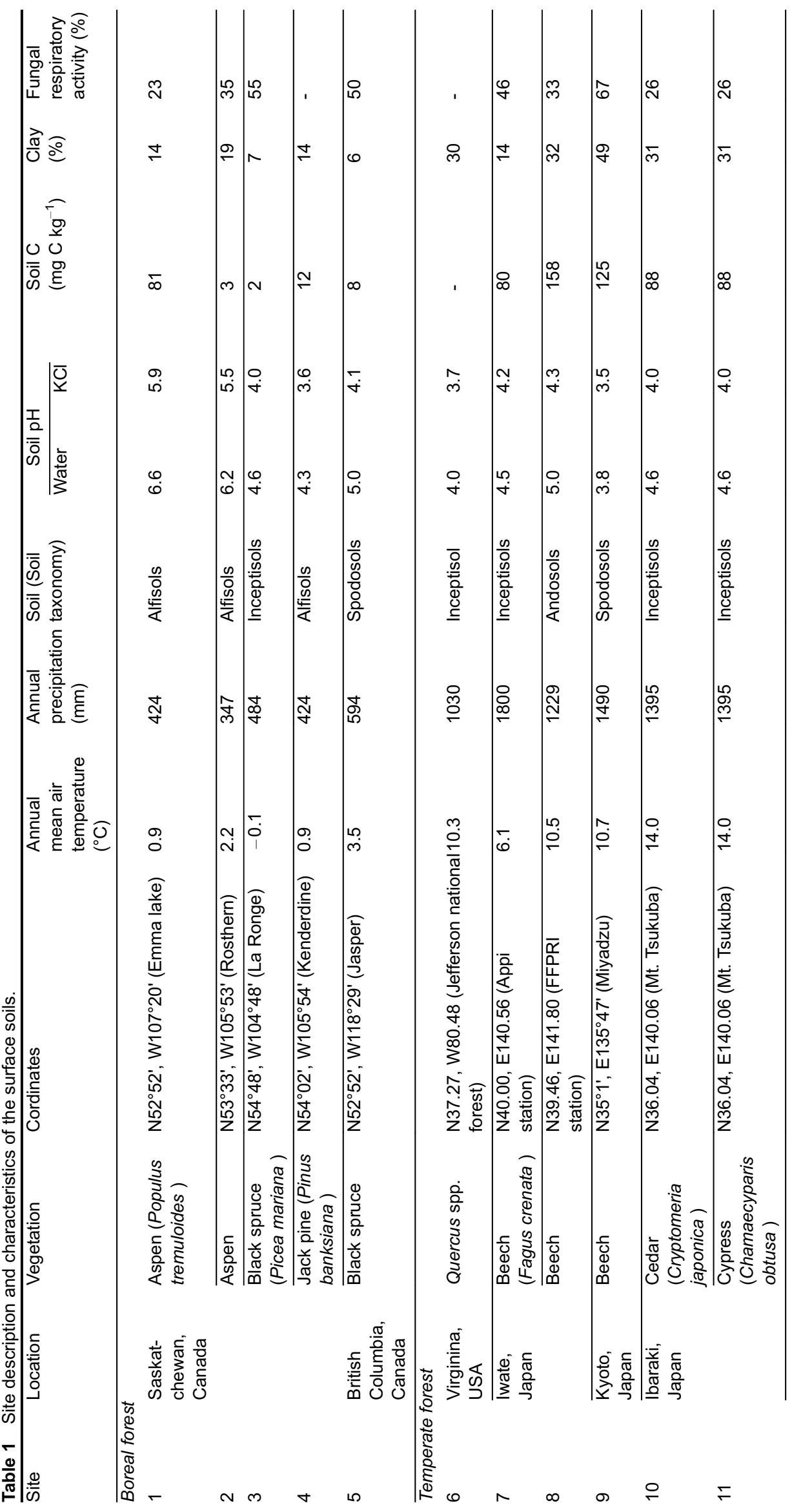




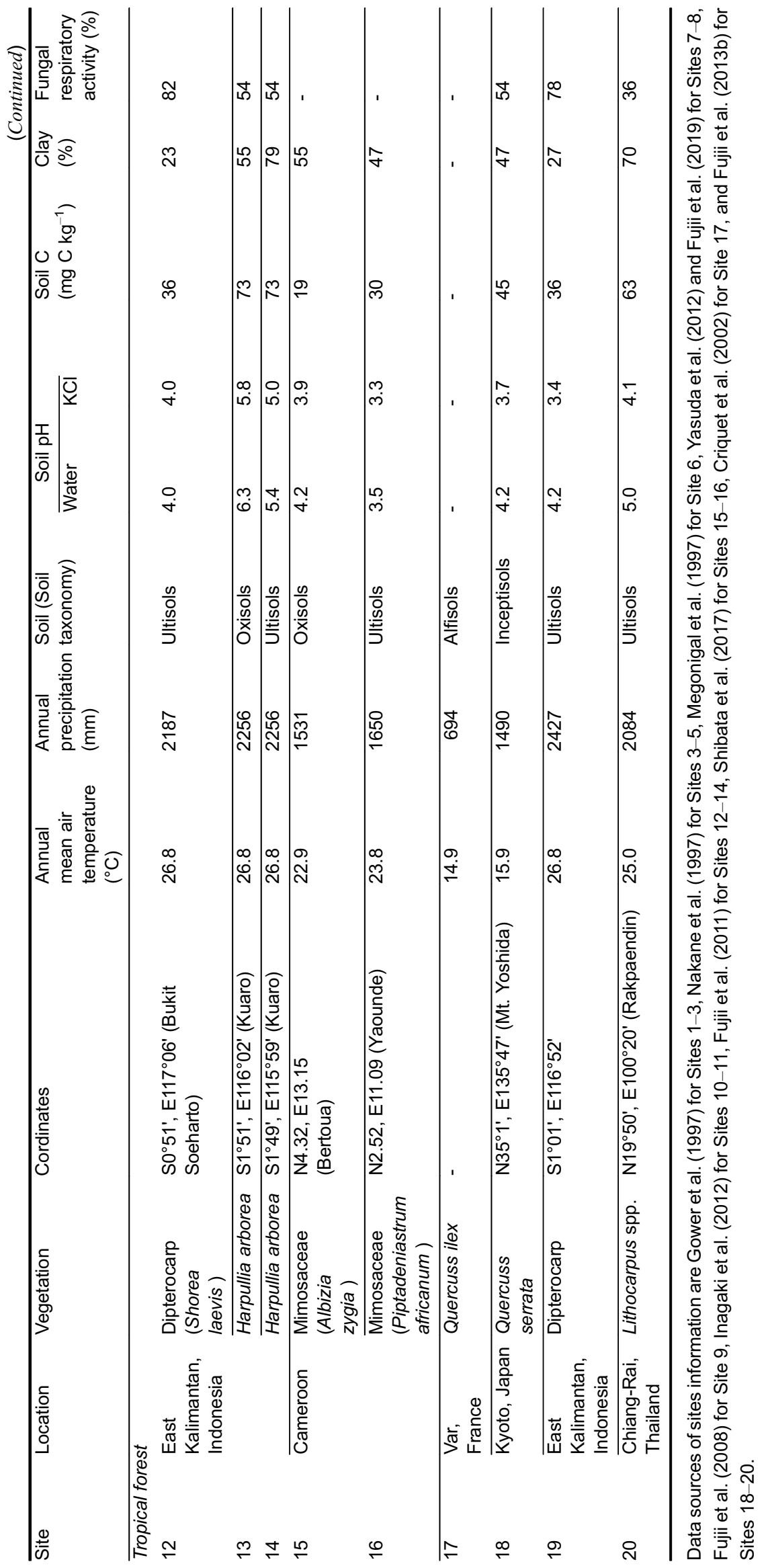


total microbial respiration was calculated using differences between ${ }^{14} \mathrm{CO}_{2}$ evolution rates of glucose-amended soils with/without inhibitor. All experiments were performed in triplicate.

\subsection{Extraction of ligninolytic enzymes}

Ligninolytic enzymes were extracted from $80 \mathrm{~g}$ of litter samples in $700 \mathrm{~mL}$ of a $0.1 \mathrm{M} \mathrm{CaCl}_{2}$ solution with $0.05 \%$ Tween 80 and $20 \mathrm{~g}$ polyvinyl polypyrrolidone at room temperature for $1 \mathrm{~h}$ on a reciprocal shaker. Suspensions were filtered through a double layer of gauze to remove floating debris then centrifuged at $12000 \mathrm{~g}$ for $20 \mathrm{~min}$ at $4^{\circ} \mathrm{C}$. Supernatants were filtered through $3.0 \mu \mathrm{m}$ and $1.0 \mu \mathrm{m}$ filters then dialyzed for $48 \mathrm{~h}$ at $4^{\circ} \mathrm{C}$ in $14 \mathrm{kDa}$ molecular mass cut-off cellulose dialysis tubing against frequently exchanged $2 \mathrm{mM}$ bis-tris [bis (2-hydroxyethyl) imino-tris (hydroxymethyl) methane] buffer, $\mathrm{pH}$ 6.0. Supernatants of each extract were concentrated in the same cellulose dialysis tubes covered with polyethylene glycol until a final volume of $1 / 10$ to $1 / 20$ of the initial volume was reached. Most litter extract samples were brown; however, the effects of turbid materials on enzyme assays are reported to be small (Archibald, 1992; Criquet et al., 1999).

\subsection{Enzyme activity assay}

For all ligninolytic enzyme activities assays, reaction times were $5 \mathrm{~min}$ at $30^{\circ} \mathrm{C}$. The enzymatic activity was measured at optimal $\mathrm{pH}, 3.0,4.5$, and 5.7 for $\mathrm{LiP}, \mathrm{MnP}$, and Lac, respectively. Extracts boiled for 15 min served as controls for the activity of LiP and Lac, and reaction in a mixture without Mn served as a control for MnP activity. One unit of enzyme activity was defined as the amount of enzyme forming $1 \mu \mathrm{mol}$ of reaction product per min and was expressed as $\mathrm{U} \mathrm{g}^{-1}$ dry matter (DM) ( $\left.\mu \mathrm{mol} \min ^{-1} \mathrm{~g}^{-1} \mathrm{DM}\right)$.

The LiP activity was measured using Azure B as a substrate (Archibald, 1992; Arora et al. 2002). The reaction mixture contained $0.5 \mathrm{~mL}$ of sodium tartrate buffer $(50 \mathrm{mM})$, $0.5 \mathrm{~mL}$ of Azure B (32 $\mu \mathrm{M}), 0.5 \mathrm{~mL}$ of $\mathrm{H}_{2} \mathrm{O}_{2}(100 \mu \mathrm{M})$, and 0.5 $\mathrm{mL}$ of enzyme extract. The reaction was initiated by adding $\mathrm{H}_{2} \mathrm{O}_{2}$. The oxidation rate of Azure B was measured with a UVVIS spectrophotometer (UV-1200, Shimadzu) at $651 \mathrm{~nm}$ based on an extinction coefficient of $\epsilon=48800 \mathrm{M}^{-1} \mathrm{~cm}^{-1}$.

$\mathrm{MnP}$ activity was measured using phenol red as a substrate (Orth et al., 1993; Arora et al. 2002). The reaction mixture contained $2.0 \mathrm{~mL}$ of sodium succinate buffer $(50 \mathrm{mM}), 2.0 \mathrm{~mL}$ of sodium lactate $(50 \mathrm{mM}), 0.8 \mathrm{~mL}$ of $\mathrm{Mn}$ sulfate $(0.1 \mathrm{mM})$ (or an equimolar amount of EDTA for control), $1.4 \mathrm{~mL}$ of phenol red $(0.1 \mathrm{mM}), 0.8 \mathrm{~mL}$ of $\mathrm{H}_{2} \mathrm{O}_{2}(50 \mu \mathrm{M}), 2.0 \mathrm{~mL}$ of albumin $(0.1 \%)$, and $1.0 \mathrm{~mL}$ of enzyme extract. The reaction was initiated by adding $\mathrm{H}_{2} \mathrm{O}_{2}$. A $2 \mathrm{~mL}$ aliquot of the reaction mixture was removed, to which $40 \mu \mathrm{L}$ of $5 \mathrm{M} \mathrm{NaOH}$ was added. The oxidation rate of the phenol red was measured at $610 \mathrm{~nm}$ based on an extinction coefficient of $\epsilon=4460 \mathrm{M}^{-1} \mathrm{~cm}^{-1}$.

Lac activity was measured using syringaldazine as a substrate (Criquet et al., 1999). The reaction mixture contained $2.5 \mathrm{~mL}$ of phosphate-citrate buffer $(0.1 \mathrm{M}), 0.1 \mathrm{~mL}$ of syringaldazine $(5 \mathrm{mM})$, and $0.5 \mathrm{~mL}$ of enzyme extract. Oxidation rate of syringaldazine to quinone was measured at $525 \mathrm{~nm}$ using syringaldazine extinction coefficient of $\epsilon=$ $65000 \mathrm{M}^{-1} \mathrm{~cm}^{-1}$.

2.6 Extraction and sequencing of RNA encoding ligninolytic enzymes

Enzyme producers and confirmation of true ligninolytic enzyme activities were examined with transcripts of RNA encoding ligninolytic enzymes. RNA extraction and cDNA synthesis used $100 \mathrm{mg}$ of composite organic layer samples ( $\mathrm{L}$, $\mathrm{F}$, and $\mathrm{H}$ ) at Site 9. Organic material was milled, extracted and purified using RNeasy Plant Mini Kit (Qiagen) following the manufacturer's protocol. Site 9 was selected due to a wide variation in $\mathrm{pH}$ and $\mathrm{Mn}$ levels among $\mathrm{L}, \mathrm{F}$, and $\mathrm{H}$ layers. Approximately $500 \mathrm{ng}$ of purified DNA-free RNA was used as a template for reverse transcription, and the reaction conducted at $50^{\circ} \mathrm{C}$ using reverse transcriptase, SuperScript $(8$ III (Invitrogen).

We used a combination of degenerate primers for class II peroxidase, peroxiF1 (5' -CGI CTS ACI TTC CAY GAY GC BAT- $3^{\prime}$ ) and peroxiR1 (5' -GT IGA GTC RAA SGG IGY ISC$\left.3^{\prime}\right)$, designed using multiple alignments of the known MnPs (Yoshida et al., 2011). PCR amplification used a Thermal Cycler Dice (Takara, Japan) in a $20 \mu \mathrm{L}$ PCR reaction of 10.0 $\mu \mathrm{L}$ Taq HS Low DNA (TaKaRa), $0.4 \mu \mathrm{L}$ of $10 \mu \mathrm{M}$ forward and reverse primer and $0.5 \mu \mathrm{L}$ cDNA template. Cycling used initial denaturation for $3 \mathrm{~min}$ at $94^{\circ} \mathrm{C}, 35$ cycles of denaturation (5 s at $\left.94^{\circ} \mathrm{C}\right)$, annealing $\left(5 \mathrm{~s}\right.$ at $\left.60^{\circ} \mathrm{C}\right)$, and elongation $(10 \mathrm{~s}$ at $68^{\circ} \mathrm{C}$ ), and a final elongation step for $5 \mathrm{~min}$ at $72^{\circ} \mathrm{C}$. PCR products of expected sizes (MnP: 400 bp) were gel purified using a Wizard $®$ SV Gel and PCR Clean-Up System (Promega). PCR amplification then used a $20.0 \mu \mathrm{L}$ PCR reaction of $0.1 \mu \mathrm{L}$ Taq HS Low DNA (TaKaRa), $2.0 \mu \mathrm{L}$ of $10 \mu \mathrm{M}$ forward and reverse primers and $1.0 \mu \mathrm{L}$ cDNA template. Cycling used in initial denaturation for $3 \mathrm{~min}$ at $95^{\circ} \mathrm{C}, 30$ cycles of denaturation $\left(10 \mathrm{~s}\right.$ at $\left.98^{\circ} \mathrm{C}\right)$, annealing $\left(30 \mathrm{~s}\right.$ at $\left.60^{\circ} \mathrm{C}\right)$, and elongation $\left(30 \mathrm{~s}\right.$ at $60^{\circ} \mathrm{C}$ ), and a final elongation step for $5 \mathrm{~min}$ at $72^{\circ} \mathrm{C}$. PCR products of expected sizes (MnP: $400 \mathrm{bp}$ ) were gel purified using Wizard® SV Gel and PCR Clean-Up System (Promega), and cloned into the pGEM-T easy vector using the pGEM-T easy Cloning Kit (Promega) for Sequencing. Nine positive clones were sequenced at Macrogen Japan and identified with blastx using the GenBank database (National Center for Biotechnology Information, USA National Library of Medicine).

\subsection{Calculations and statistics}

All results are expressed on an oven-dry weight basis $\left(70^{\circ} \mathrm{C}\right.$, $48 \mathrm{~h})$ and are the mean of three replicates. Statistical significance of simple linear regressions was tested using a significance level of 0.05 unless otherwise stated. The statistical analyses were performed with SigmaPlot 12.3 (SPSS Inc., 2013). 


\section{Results}

3.1 Physicochemical properties of organic layers and soil samples

Soil $\mathrm{pH}$ (water) was negatively correlated with annual precipitation ( $r=-0.44, p<0.10, n=16$; Table 1$)$. The fungal respiratory activity in surface soil $(0-5 \mathrm{~cm}$; A horizon) was negatively correlated with soil $\mathrm{pH}$ (water) $(r=-0.60, p<0.05$, $n=16$; Table 1). Organic layer $\mathrm{pH}$ ( $\mathrm{FH}$ or $\mathrm{L}$, if not) was positively correlated with $\mathrm{pH}(\mathrm{KCl})$ of the surface mineral soil $(r=0.60, p<0.05, n=16$; Table 2$)$. The soils overlaid by $\mathrm{FH}$ layers were consistently acidic $[\mathrm{pH}(\mathrm{KCl})<4.0$; Table 2].

The lignin concentrations in fresh litter varied widely from $14 \%$ to $43 \%$ (Table 2). As expected, $\mathrm{C} / \mathrm{N}$ and lignin/ $\mathrm{N}$ ratios were significantly $(p<0.05)$ lower in $\mathrm{N}$-fixing forests of Cameroon (Sites 15, 16) than in the other sites (Sites 1-14). Litter Mn/lignin ratios decreased with depth $(\mathrm{L}>\mathrm{FH})$ at Site 7 , 9, 12-16, except for Site 8 (Table 2).

\subsection{Litter decomposition rate factor}

Organic layer $\mathrm{C}$ stocks varied widely from $2.0 \mathrm{Mg} \mathrm{C}^{-1}$ in Cameroon (Sites 15,16 ) to $30.9 \mathrm{Mg} \mathrm{C}^{-1}$ in Japan (Site 9; Table 3). Carbon tended to fall within lower values at higher mean annual air temperature (Table 3). Litter decomposition rate ranged from $0.05 \mathrm{yr}^{-1}$ in Japan (Site 9) to $2.25 \mathrm{yr}^{-1}$ in Cameroon (Sites 15, 16) (Table 3). Despite limitations due differences in sampling periods and an assumption of "steadystate" forest ecosystems, litter decomposition rate correlated positively with mean annual air temperature $(r=0.80, p<0.05$, $n=16$; Fig. 1A), negatively with organic layer $\mathrm{pH}(r=-0.60$, $p<0.05, n=16$; Fig. 1B), and negatively with the fresh litter $\mathrm{Mn} /$ lignin ratio $(r=-0.44, p<0.10, n=16$; Fig. $1 \mathrm{C})$. No significant correlations between organic layer $\mathrm{C}$ and lignin/ $\mathrm{N}$ ratio or litter $\mathrm{C}$ turnover and lignin/ $\mathrm{N}$ ratio were observed. (Fig. 1D), However, organic layer $C$ tended to fall within higher values at higher lignin/ $\mathrm{N}$ ratio (Fig. 1D).

\subsection{Ligninolytic enzyme activities}

Consistent with our first hypothesis, MnP activities in L layers correlated positively with mean air temperature during the sampling month (Fig. 2A). In contrast, no correlations between air temperature and LiP or Lac activities were found (Fig. 2B, C). In contrast to detection of $\mathrm{MnP}$ activities in a broad $\mathrm{pH}$ range (Fig. 3A), high LiP activity was detected in acidic $\mathrm{FH}$ layers ( $\mathrm{pH}>4.3$; Fig. $3 \mathrm{~B})$ and where lignin concentrations were greater than $35 \%$ (Fig. 4). Expression of LiP activity was limited to litter $\mathrm{pH}$ below 6.0 (Fig. 3B): Lac activities were detected in litter layers across a broad $\mathrm{pH}$ range (3.5-7.9), as seen in MnP activities (Fig. 3A, C). Lac activity was commonly found in fresh litter layers, regardless of $\mathrm{pH}$ (Fig. 3C).

Two boreal aspen forests (Sites 1,2) showed similar MnP and Lac activities, while two black spruce forests (Sites 4, 5) exhibited LiP activity but not MnP and Lac activity (Table 4). Expression patterns of MnP, LiP, and Lac in temperate forest litter differed even among beech forest sites (Sites 7-9; Table 4). The MnP activity was replaced by LiP in deeper layers at Site 9 (Table 4). MnP activity in tropical forests was detected at all sites (Sites 12-16), while LiP activity was detected only in the dipterocarp forest (Site 12; Table 4). LiP activity increased when litter lignin concentration exceeded $35 \%$ (Fig. 4). Still, no correlation between LiP activities and the litter lignin/ $\mathrm{N}$ ratios or lignin concentration existed (Table 4). $\mathrm{MnP}$ activity was not correlated with litter Mn concentration but did correlate with litter Mn/lignin ratio (Fig. 5A) and with fungal respiratory activity (Fig. 5B).

\subsection{Detection of peroxidase transcripts in the organic layers}

We found three transcripts of manganese peroxidase partial [uncultured fungus] (Accession no. AVI23960) in L, F, and $\mathrm{H}$ layers and two transcripts of manganese peroxidase 2 [Phlebia sp. MG60] (Accession no. BAP05605) in the F layer in samples from Site 9. We also detected two transcripts similar to manganese peroxidase 1 [Pluteus cervinus] (Accession no. KDQ28248), one transcript similar to manganese peroxidase partial [uncultured fungus] (Accession no. AY06829). Both were found in beech forests, and one transcript was similar to lignin peroxidase [Phanerochaete chrysosporium] (Accession no. ABT17198) (Table S1). All transcripts found in samples from Site 9 exhibited similarity with peroxidases produced by Polyporales. The distribution of these transcripts was consistent with patterns of enzyme activities in the same samples (Table 4).

\section{Discussion}

Ligninolytic enzyme activities under field conditions are hypothesized to be regulated primarily by temperature across global climatic gradients, and secondarily by local vegetation and soil types (Aerts, 1997). Increased MnP activity at higher air temperature supports this hypothesis (Fig. 1A). However, LiP and Lac activity vary widely due to the site-specific properties other than temperature, e.g., vegetation and soil conditions (Fig. 2B,C).

4.1 Effects of vegetation on ligninolytic enzyme activity in forest floor layers

Vegetation type influences ligninolytic enzyme activities through effects on litter (substrate) quality and related dominant fungal communities (Berg et al., 2007; Osono, 2007). For example, Ganoderma lucidum preferentially produces $\mathrm{MnP}$ in aspen woods but not in pine woods (Hatakka, 2001). In our study, vegetation effects are supported by consistent patterns of MnP activity detection in two aspen forest sites (Sites 1, 2), LiP activity detection in two black spruce forest sites (Sites 4, 5), and detection of MnP, $\mathrm{LiP}$, and Lac activities in three beech forest sites (Sites 7-9) (Table 4). These findings can be interpreted as control of enzyme activity and dominant fungal communities by 


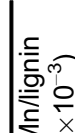

$|+|$

\๐:

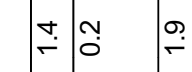

$\mid$

$\mid$

$|+|$



이용

$\operatorname{los}^{10}$

舟

○:

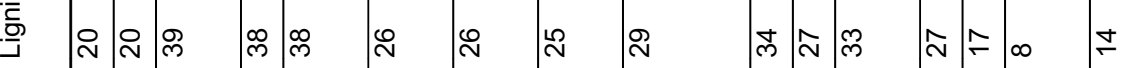

孞



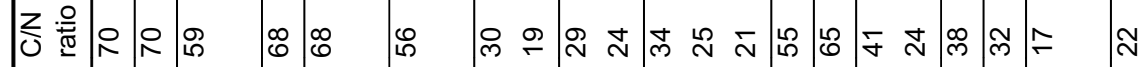
高

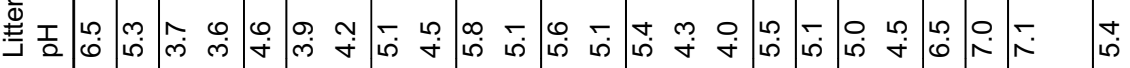

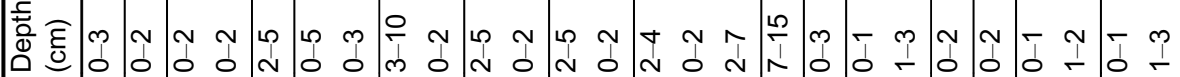

离)

离 $I$

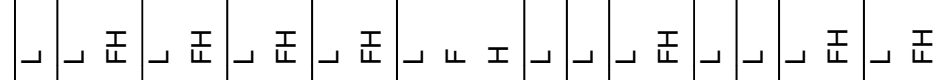

$\frac{2}{\pi}$ I

응

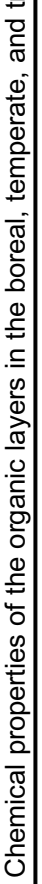

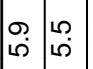

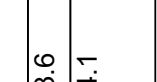

a
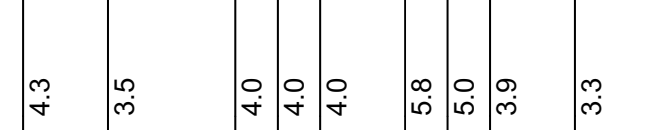

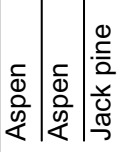

\section{造}

$\frac{\dot{8}}{2}$

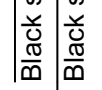

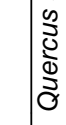

동


产 $\frac{0}{\mathrm{a}}$

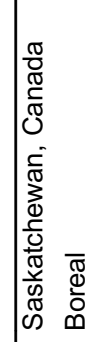

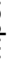

营

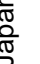
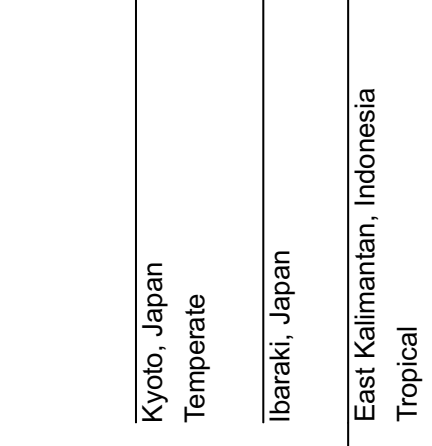

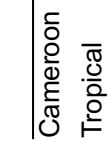

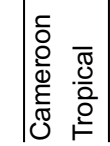

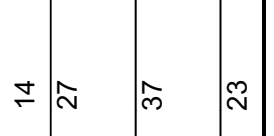

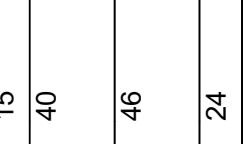



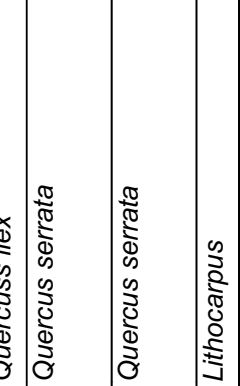

牙高

$\infty$ 过

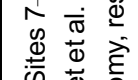

के के

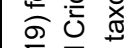

总

远

屯

눌

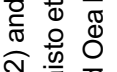

는 $\frac{\pi}{\sqrt{0}}$

哭

屯

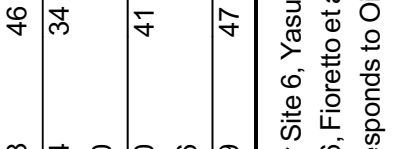

ம்

는

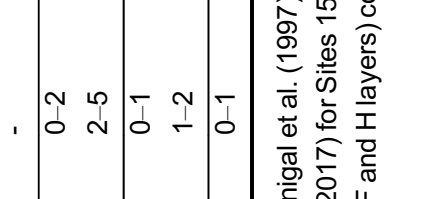

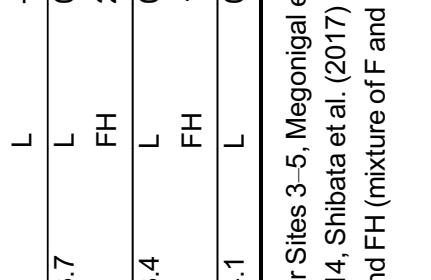

-

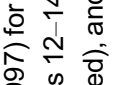
要离

त्ञ

产 穴

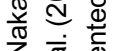

西

野

这

흥ㅎㅁ

रิ

的

बं

बत

这

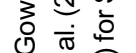

ब $\frac{\pi}{0}$

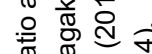

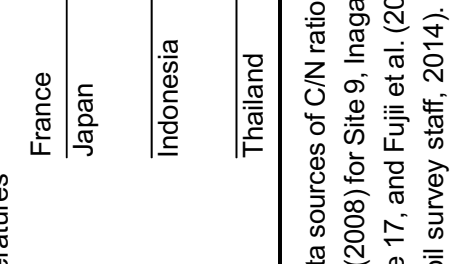

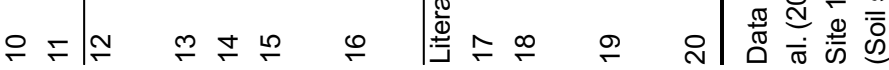


Table 3 Litterfall, organic layer carbon stock, and decomposition rate factor in the boreal, temperate, and tropical forests studied.

\begin{tabular}{|c|c|c|c|c|c|}
\hline$\overline{\text { Site }}$ & Location & Vegetation & $\begin{array}{l}\text { Litterfall-C } \\
\left(\mathrm{Mg} \mathrm{C} \mathrm{ha}^{-1} \mathrm{yr}^{-1}\right)\end{array}$ & $\begin{array}{l}\text { Organic layer } \mathrm{C} \\
\text { stock }\left(\mathrm{Mg} \mathrm{C}^{-1} \mathrm{ha}^{-1}\right)\end{array}$ & $\begin{array}{l}\text { Decomposition rate } \\
\text { factor }\left(\mathrm{yr}^{-1}\right)\end{array}$ \\
\hline$\overline{1}$ & Saskatchewan, Canada (Boreal) & Aspen & 1.2 & 7.0 & 0.17 \\
\hline 2 & & Aspen & 1.2 & 6.5 & 0.18 \\
\hline 3 & & Jack pine & 0.5 & 10.5 & 0.05 \\
\hline 4 & & Black spruce & 1.3 & 5.4 & 0.25 \\
\hline 5 & British Columbia, Canada (Boreal) & Black spruce & 1.3 & 24.5 & 0.05 \\
\hline$\overline{6}$ & Virginina, USA (Temperate) & Quercus spp. & 3.0 & 5.1 & 0.59 \\
\hline 7 & $\overline{\text { Iwate, Japan (Temperate) }}$ & Beech & 1.6 & 8.4 & 0.19 \\
\hline 8 & & Beech & 1.8 & 8.0 & 0.22 \\
\hline 9 & Kyoto, Japan (Temperate) & Beech & 2.1 & 30.6 & 0.07 \\
\hline 10 & Ibaraki, Japan & Cedar & 3.6 & 7.2 & 0.50 \\
\hline 11 & & Cypress & 3.1 & 4.1 & 0.76 \\
\hline$\overline{12}$ & East Kalimantan, Indonesia (Tropical) & Dipterocarp & 4.1 & 3.5 & 1.17 \\
\hline 13 & & Harpullia arborea & 4.8 & 4.1 & 1.17 \\
\hline 14 & & Harpullia arborea & 4.0 & 2.9 & 1.38 \\
\hline 15 & Cameroon (Tropical) & Mimosaceae & 4.5 & 2.0 & 2.25 \\
\hline 16 & & Mimosaceae & 4.5 & 2.0 & 2.25 \\
\hline
\end{tabular}

\section{Literatures}

\begin{tabular}{llllll}
17 & France (Temperate) & Quercuss ilex & - & - & - \\
18 & Japan (Temperate) & Quercuss serrata & 2.9 & 3.4 & 0.85 \\
19 & $\begin{array}{l}\text { East Kalimantan, } \\
\text { Indonesia (Tropical) }\end{array}$ & Dipterocarp & 3.6 & 4.5 & 0.80 \\
& & & & 2.6 & 1.54 \\
\hline
\end{tabular}

Data sources of litterfall, organic layer C stock, and C/N ratio are Gower et al. (1997) for Sites 1-3, Nakane et al. (1997) for Sites 3-5, Megonigal et al. (1997) for Site 6, Yasuda et al. (2012) and Fujii et al. (2019) for Sites 7-8, Fujii et al. (2008) for Site 9, Inagaki et al. (2012) for Sites 10-11, Fujii et al. (2011) for Sites 12-14, and Shibata et al. (2017) for Sites 15-16.

common traits shared by litterfall and woody materials, e.g., lower lignin and higher $\mathrm{pH}$ of aspen litter and woody debris.

Fungal enzyme production is triggered by $\mathrm{N}$ starvation (Kirk and Farrell, 1987), and LiP production may be limited in litter layers with low $\mathrm{C} / \mathrm{N}$ and lignin/ $\mathrm{N}$ ratios. Lack of LiP activity in $\mathrm{N}$-fixing Mimosaceae forests (Sites 15, 16; Table 4) is consistent with this hypothesis. However, LiP detection over a broad range of lignin/ $\mathrm{N}$ and $\mathrm{C} / \mathrm{N}$ ratio (Table 4) suggests that lignin/ $\mathrm{N}$ or $\mathrm{C} / \mathrm{N}$ ratio may not be a sensitive indicator of $\mathrm{N}$ starvation that triggers fungal LiP production. Further, high LiP activity at lignin/ $\mathrm{N}$ ratios $>25$ and at lignin concentration $>35 \%$ (Fig. 4) suggest that high lignin concentration is a prerequisite for expression of LiP activity. Low $\mathrm{pH}$ and LiP producers in the deeper organic layers are additional requirements (Fig. 3B). This suggestion is consistent with the finding that LiP evolved in acidic conditions favorable for oxidation of recalcitrant nonphenolic structures of lignin (Oyadomari et al., 2003).

The MnP activity is common at all sites except, for black spruce forests (Table 4) sites, MnP activities in temperate and tropical forests are comparable to activity reported for a Mediterranean oak forest (Criquet et al., 1999; Table 4). Further, transcripts encoding $\mathrm{MnP}$ in a Japanese beech forest are similar to those found in a Belgium beech forest (AVI23960; Kellner et al., 2014) and transcripts from white- rot fungi Phlebia sp. in Japan (BAG12561; Kamei et al., 2008) (Table S1). We cannot exclude all possibilities that the ligninolytic enzyme activities encompass pseudo-positive reactions. However, the occurrence of enzymes and efficient producers (white-rot basidiomycete fungi or Polyporales) are supported by detection of several transcripts of RNA that encodes ligninolytic enzymes (Table S1). This result partly explains why MnP activity is increased under favorable conditions for fungal growth (Fig. 5B). The positive correlation between $\mathrm{MnP}$ activity and litter $\mathrm{Mn} /$ lignin ratio (Fig. $5 \mathrm{~A}$ ) suggests an important link between $\mathrm{Mn}$ and expression of $\mathrm{MnP}$ activity (Berg et al., 2007). $\mathrm{Mn}^{2+}$ is oxidized to $\mathrm{Mn}^{3+}$ in lignin oxidation by $\mathrm{MnP}$. The complex of $\mathrm{Mn}^{3+}$ - di-carboxylic organic acids (e.g., oxalate, malate, and malonate) attacks the phenol structure of lignin as diffusible oxidant (Hatakka, 2001). An increase in litter decomposition related to Mn/lignin ratio (Fig. 1C) also supports the hypothesis that high $\mathrm{Mn}$ availability could stimulate litter decomposition through increased microbial MnP activity (Berg et al., 2007). Note that the wide variation in $\mathrm{MnP}$ activity associated with $\mathrm{Mn}$ / lignin ratios implies that $\mathrm{MnP} /$ lignin ratios and $\mathrm{Mn}$ availability are conditions that stimulate MnP activity. Such stimulation is highly dependent on of MnP producers (fungi), consistent with the positive correlation between $\mathrm{MnP}$ activity and fungal 



Fig. 1 Litter decomposition rates related to mean annual air temperature (A), litter layer $\mathrm{pH}(\mathrm{B})$, fresh litter $\mathrm{Mn} /$ lignin ratio (C), and fresh litter lignin/N ratio (D). Reference data are from Criquet et al. (2000) and Fujii et al. (2013b).

respiratory activity (Fig. 5B). Litter Mn/lignin effects, as well as warm climate (Fig. 1A), promote rapid litter turnover in tropical forests (Fig. 1C).

4.2 Effects of soil pH on ligninolytic enzyme activity in organic layers

Soil $\mathrm{pH}$ influences ligninolytic enzyme activity directly through its impact on organic layer $\mathrm{pH}$ and indirectly by alteration of litter quality and fungal communities (Fujii and Hayakawa, 2013; Tables 1 and 2). Low pH retards microbial and faunal litter decomposition and leads to accumulation of acidic humified layers poor in Mn (Fig. 1B; Staaf, 1987). We hypothesize that production and activity of enzymes are maximized in a $\mathrm{pH}$ range close to their optimal $\mathrm{pH}$ values (Fujii et al., 2013a), 2.5-3.0 for LiP, 4.5-5.0 for MnP, and 3.0-5.7 for Lac in pure culture systems (Tien and Kirk, 1983; Bollag and Leonowicz, 1984; Glenn and Gold, 1985; Rüttimann-Johnson et al., 1994). Patterns of LiP, MnP, and Lac activity follows reported optimal $\mathrm{pH}$ ranges, although a gap exists between $\mathrm{pH}$ ranges for field activity and optimal $\mathrm{pH}$ obtained from pure culture (Fig. 3). The co-occurrence of LiP, MnP, and Lac is not common (Table 4). This finding can be explained by differences in optimal pH ranges (Fig. 3) and competition among enzyme producers (Rothschild et al., 1999). MnP displays a relatively wide optimal $\mathrm{pH}$ range (Fig. $5 \mathrm{~A}$ ) and its activity increases with the activity of broad range of fungal species (Fig. 5B).

Rapid litter turnover without development of an acidified $\mathrm{FH}$ layer (Fig. 2B) contributes to favorable (less acidic) $\mathrm{pH}$ conditions for expression of MnP and Lac activity in $L$ layers (Fig. 3A, C), consistent with greater microbial and enzyme activities in upper layers (Šnajdr et al., 2008). Compared to $\mathrm{LiP}$, a broader range of basidiomycete fungi can produce MnP. Lac is also produced by the broader fungal community including non-basidiomycete fungi, ascomycetes, actinomycetes, and some bacteria (Hofrichter, 2002; Baldrian, 2006). The higher availability of substrate (i.e., phenolics) at higher $\mathrm{pH}$ is also favorable for MnP and Lac producers (Sinsabaugh, 2010). These suggestions contrast with high LiP activity at low $\mathrm{pH}$ (Fig. 3B). LiP is produced only by the specific basidiomycete fungi, Polyporales (e.g., Phlebia sp., Phanerochaete sp.) (Morgenstern et al., 2008; Kellner et al., 2014). Highly acidic and lignin-rich environments and admixing of woody debris in $\mathrm{FH}$ layers are favorable for LiP production (Figs. 3B and 4). 


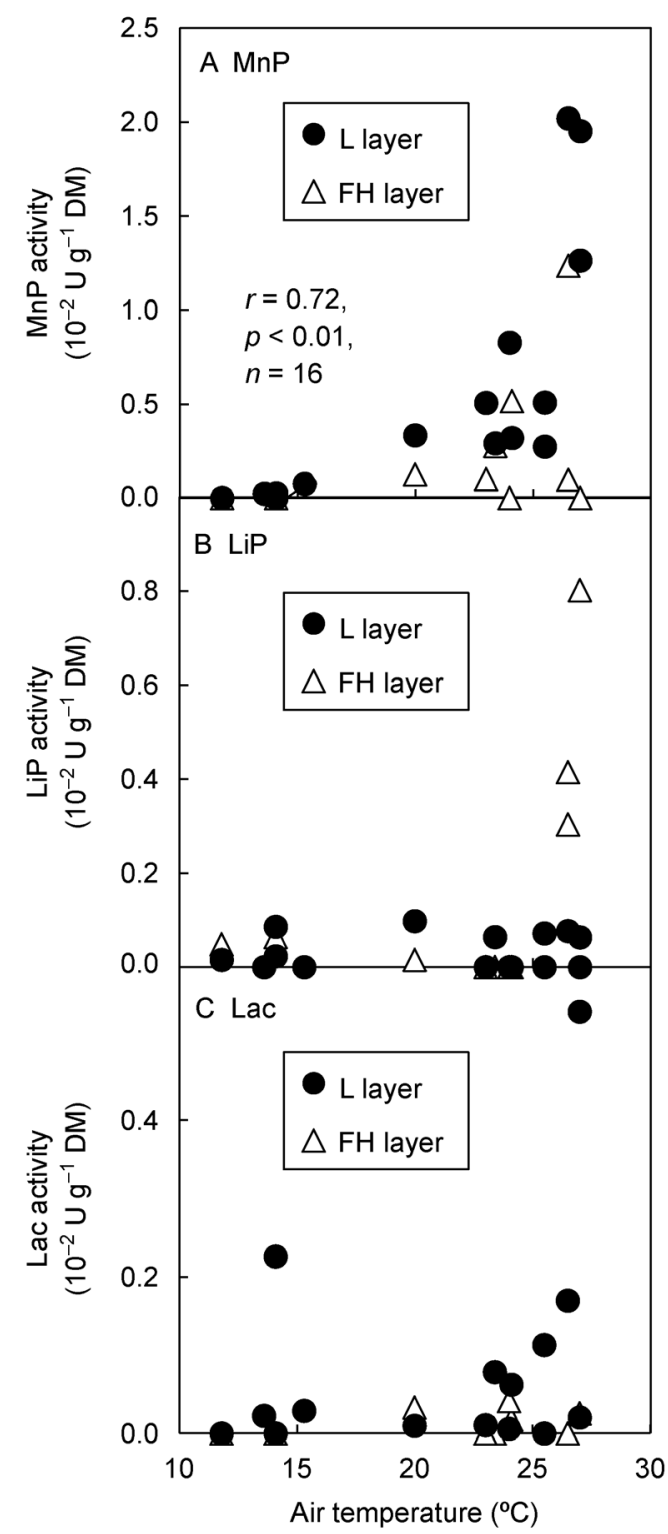

Fig. 2 The activity of manganese peroxidase (A), lignin peroxidase $(B)$, and laccase $(C)$ related to air temperature during the sampling period.

4.3 Pathways of climatic control on ligninolytic enzyme activities and litter carbon turnover

At global climatic scale, litter turnover is more rapid in warmer climates (Fig. 1A), consistent with Trumbore (2000). Litter fragmentation by soil animals (e.g., termite) is known to promote litter $\mathrm{C}$ turnover in tropics, but rapid litter turnover ultimately requires efficient lignin degradation by fungal enzymes (Fujii et al., 2018). Significant temperature dependency of lignin degradation is proposed based on the thermodynamic argument that enzymatic reactions decomposing structurally complex, aromatic molecules, such as lignin, require higher activation energy than reactions that



Fig. 3 The activity of manganese peroxidase (A), lignin peroxidase $(B)$, and laccase $(C)$ related to organic layer $\mathrm{pH}$.



Fig. 4 Lignin peroxidase activity related to litter lignin concentration. 
Table 4 Mean $(n=3)$ ligninolytic enzyme activities in the organic layers in the boreal, temperate, and tropical forests studied.

\begin{tabular}{|c|c|c|c|c|c|c|}
\hline$\overline{\text { Site }}$ & Location & Vegetation/Soil & Layer & $\begin{array}{l}\text { MnP activity } \\
\left(10^{-2} \mathrm{Ug}^{-1} \mathrm{DM}\right)\end{array}$ & $\begin{array}{l}\text { LiP activity } \\
\left(10^{-2} \mathrm{Ug}^{-1} \mathrm{DM}\right)\end{array}$ & $\begin{array}{l}\text { Lac activity } \\
\left(10^{-2} \mathrm{Ug}^{-1} \mathrm{DM}\right)\end{array}$ \\
\hline$\overline{1}$ & $\begin{array}{l}\text { Saskatchewan, } \\
\text { Canada }\end{array}$ & Aspen & $\mathrm{L}$ & 0.08 & b.d.I. & 0.03 \\
\hline 2 & Boreal & Aspen & $\mathrm{L}$ & 0.02 & b.d.I. & 0.02 \\
\hline \multirow[t]{2}{*}{3} & & Jack pine & $\mathrm{L}$ & 0.02 & 0.02 & 0.23 \\
\hline & & & $\mathrm{FH}$ & b.d.l. & 0.06 & b.d.I. \\
\hline 4 & & Black spruce & $\mathrm{L}$ & b.d.I. & 0.09 & 0.00 \\
\hline \multirow[t]{2}{*}{5} & $\begin{array}{l}\text { British Columbia, } \\
\text { Canada }\end{array}$ & Black spruce & $\mathrm{L}$ & b.d.l. & 0.02 & b.d.I. \\
\hline & Boreal & & $\mathrm{FH}$ & b.d.l. & 0.05 & b.d.l. \\
\hline \multirow[t]{2}{*}{6} & Virginina, USA & Quercus spp & $\mathrm{L}$ & 0.32 & b.d.I. & 0.06 \\
\hline & Temperate & & $\mathrm{FH}$ & 0.51 & b.d.l. & 0.02 \\
\hline \multirow[t]{2}{*}{7} & Iwate, Japan & Beech & $\mathrm{L}$ & 0.33 & 0.10 & 0.01 \\
\hline & Temperate & & $\mathrm{FH}$ & 0.51 & b.d.l. & 0.02 \\
\hline \multirow[t]{2}{*}{8} & & Beech & $\mathrm{L}$ & 0.29 & 0.06 & 0.08 \\
\hline & & & $\mathrm{FH}$ & 0.28 & b.d.l. & b.d.l. \\
\hline \multirow[t]{3}{*}{9} & Kyoto, Japan & Beech & $\mathrm{L}$ & 2.02 & 0.08 & 0.17 \\
\hline & Temperate & & $\mathrm{F}$ & 1.23 & 0.30 & b.d.l. \\
\hline & & & $\mathrm{H}$ & 0.10 & 0.41 & b.d.l. \\
\hline 10 & Ibaraki, Japan & Cedar & $\mathrm{L}$ & 0.51 & b.d.I. & 0.11 \\
\hline 11 & Temperate & Cypress & $\mathrm{L}$ & 0.27 & 0.07 & b.d.I. \\
\hline \multirow[t]{2}{*}{12} & Indonesia & Dipterocarp & $\mathrm{L}$ & 1.95 & 0.06 & 0.02 \\
\hline & Tropical & & $\mathrm{FH}$ & b.d.l. & 0.80 & 0.03 \\
\hline 13 & & Harpullia arborea (Oxisols) & $\mathrm{L}$ & 0.76 & b.d.I. & 0.50 \\
\hline 14 & & Harpullia arborea (Ultisols) & $\mathrm{L}$ & 1.22 & b.d.I. & 0.54 \\
\hline \multirow[t]{2}{*}{15} & Cameroon & Mimosaceae (Oxisols) & $\mathrm{L}$ & 0.51 & b.d.I. & 0.01 \\
\hline & Tropical & & $\mathrm{FH}$ & 0.10 & b.d.l. & b.d.l. \\
\hline 16 & & Mimosaceae (Ultisols) & $\mathrm{L}$ & 0.83 & b.d.I. & 0.01 \\
\hline \multicolumn{7}{|c|}{ Literatures } \\
\hline 17 & France & Quercuss ilex & L & $0.60-2.7$ & b.d.l. & $0.0-3.7$ \\
\hline \multirow[t]{2}{*}{18} & Japan & Quercuss serrata & $\mathrm{L}$ & 3.56 & b.d.I. & b.d.I. \\
\hline & & & $\mathrm{FH}$ & b.d.l. & 0.26 & b.d.l. \\
\hline \multirow[t]{2}{*}{19} & Indonesia & Dipterocarp & $\mathrm{L}$ & 3.39 & b.d.I. & 0.09 \\
\hline & & & $\mathrm{FH}$ & b.d.l. & 0.88 & b.d.l. \\
\hline 20 & Thailand & Lithocarps & $\mathrm{L}$ & 0.73 & b.d.I. & b.d.I. \\
\hline
\end{tabular}

b.d.I. = below detection limit. Data sources are Criquet et al. (2000) for Site 17 and Fujii et al. (2013b) for Sites. 18-20.

decompose structurally simpler molecules (Mikan et al., 2002). Such energetics are consistent with the slow turnover of litters with high lignin/ $\mathrm{N}$ ratios in boreal forests (Fig. 1D; Meentemeyer, 1978). However, fresh litter lignin/N ratios do not fully explain the wide variation in litter $C$ turnover at global scale in our study (Fig. 1D). An increase in MnP activity in warmer climate (Fig. 2A) could be a critical mechanism for efficient lignin degradation.

High $\mathrm{Mn} /$ lignin ratios of litter lead to high MnP activities (Fig. $5 \mathrm{~A}$ ) as a control on enzyme activity and litter $C$ turnover, as well as rapid litter turnover (Fig. 1C). A snapshot of enzymatic activities from a single sampling period cannot be extrapolated or related directly with organic layer $\mathrm{C}$ or turnover data on annual or longer time scales. Still, high Mn/lignin ratios could promote lignin degradation through stimulating MnP activity. Further, direct effects of warmer climates on elevated microbial and faunal activity correlates with litter decomposition rates that are enhanced by the high $\mathrm{Mn}$ availability and MnP activity (Bonnarme and Jeffries, 1990; Berg et al., 2007). The critical roles of $\mathrm{MnP}$ in litter turnover at global climatic gradient is supported by the widespread occurrence of $\mathrm{MnP}$ in L layers (Table 4; Kellner et al., 2014) and by increased MnP activity and litter Mn/lignin ratios in warmer climates in our study (Fig. 5A). Under the presence of MnP-producing fungi and sufficient $\mathrm{H}_{2} \mathrm{O}_{2}$ availability, litter $\mathrm{Mn}$ /lignin ratios may be a useful indicator of lignin decomposability and could explain rapid litter $C$ turnover in warmer climates from the viewpoint of lignin degradation. 


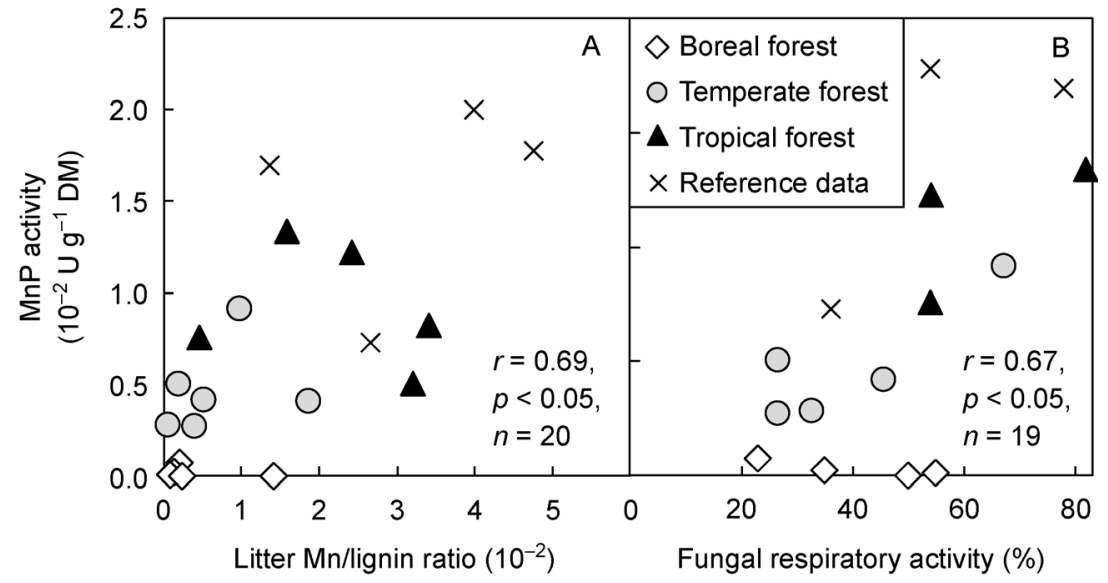

Fig. 5 Manganese peroxidase activity related to fresh litter $\mathrm{Mn} /$ lignin ratio (A) and fungal respiratory activity (B). Data are expressed as mass-weighted means for $\mathrm{L}$ and FH layers. Reference data are from Criquet et al. (2000) and Fujii et al. (2013b).

\section{Conclusions}

MnP activity in fresh litter layers increases with increasing air temperature. Fresh litter $\mathrm{Mn} /$ lignin ratios correlate positively with $\mathrm{MnP}$ activity and contribute to faster litter turnover in warmer climates. The Lac and LiP activities are affected by organic layer and soil $\mathrm{pH}$ as well as climate; Lac activity is limited to fresh litter, and LiP activity is limited to acidified and humified layers, respectively. The widespread occurrence of $\mathrm{MnP}$ and an increase in MnP activity in warmer climates are reasons for efficient lignin degradation in tropics and during summer seasons. High Mn/lignin ratio in fresh litter could be an indicator of lignin degradability by MnP-producing fungi across global climate gradients. A limited number of data sets were available to support our study, and additional research is warranted for expanding the database and integrating data sets into global patterns of ligninolytic enzyme activity and litter degradation.

\section{Acknowledgments}

We thank the Kinki and Chugoku Regional Forest Office of the Ministry of Agriculture, Forestry and Fisheries of Japan and the Experimental Forest of the Tropical Rainforest Research Center at Mulawarman University for allowing us to conduct studies at the experimental sites.

\section{Electronic supplementary material}

Supplementary material is available in the online version of this article at https://doi.org/10.1007/s42832-020-0042-6 and is accessible for authorized users.

\section{References}

Aerts, R., 1997. Climate, leaf litter chemistry and leaf litter decomposition in terrestrial ecosystems: a triangular relationship. Oikos
79, $439-449$.

Allen, S.E., Grimshaw, H.M., Parkinson, J.A., Quarmby, C., 1974. Chemical Analysis of Ecological Materials. Wiley, New York.

Anderson, J.P.E., Domsch, K.H., 1973. Quantification of bacterial and fungal contributions to soil respiration. Archives of Microbiology 93, 113-127.

Archibald, F.S., 1992. A new assay for lignin-type peroxidases employing the dye azure B. Applied and Environmental Microbiology 58, 3110-3116.

Arora, D.S., Chander, M., Gill, P.K., 2002. Involvement of lignin peroxidase, manganese peroxidase and laccase in degradation and selective ligninolysis of wheat straw. International Biodeterioration \& Biodegradation 50, 115-120.

Baldrian, P., 2006. Fungal laccases occurrence and properties. FEMS Microbiology Reviews 30, 215-242.

Berg, B., Steffen, K.T., McClaugherty, C., 2007. Litter decomposition rate is dependent on litter Mn concentrations. Biogeochemistry 82 , 29-39.

Blair, J.M., 1988. Nitrogen, sulfur and phosphorus dynamics in decomposing deciduous leaf litter in the southern Appalachians. Soil Biology \& Biochemistry 20, 693-701.

Bollag, J.M., Leonowicz, A., 1984. Comparative studies of extracellular fungal laccases. Applied and Environmental Microbiology 48, 849-854.

Bonnarme, P., Jeffries, T.W., 1990. Mn (II) regulation of lignin peroxidase and manganese-dependent peroxidase from lignindegrading white rot fungi. Applied and Environmental Microbiology 56, 210-217.

Criquet, S., Farnet, A.M., Tagger, S., Le Petit, J., 2000. Annual variations of phenoloxidase activities in an evergreen oak litter: influence of certain biotic and abiotic factors. Soil Biology \& Biochemistry 32, 1505-1513.

Criquet, S., Tagger, S., Vogt, G., lacazio, G., Lepetit, J., 1999. Laccase activity of forest litter. Soil Biology \& Biochemistry 31, 1239-1244.

Fioretto, A., Papa, S., Pellegrino, A., Fuggi, A., 2007. Decomposition dynamics of Myrtus communis and Quercus ilex leaf litter: Mass loss, microbial activity and quality change. Applied Soil Ecology $36,32-40$. 
Fujii, K., Funakawa, S., Hayakawa, C., Kosaki, T., 2008. Contribution of different proton sources of pedogenetic soil acidification in forested ecosystems in Japan. Geoderma 144, 478- 490.

Fujii, K., Hartono, A., Funakawa, S., Uemura, M., Kosaki, T., 2011. Acidification of tropical forest soils derived from serpentine and sedimentary rocks in East Kalimantan, Indonesia. Geoderma 160, 311-323.

Fujii, K., Hayakawa, C., 2020. Effects of land use change on turnover and storage of soil organic matter in a tropical forest. Plant and Soil 446, 425-439.

Fujii, K., Hayakawa, C., Inagaki, Y., Ono, K., 2019. Sorption reduces the biodegradation rates of multivalent organic acids in volcanic soils rich in short-range order minerals. Geoderma 333, 188-199.

Fujii, K., Morioka, K., Hangs, R., Funakawa, S., Kosaki, T., Anderson, D.W., 2013b. Importance of climate and parent material on soil formation in Saskatchewan, Canada as revealed by soil solution studies. Pedologist 57, 27-44.

Fujii, K., Shibata, M., Kitajima, K., Ichie, T., Kitayama, K., Turner, B.L., 2018. Plant-soil interactions maintain biodiversity and functions of tropical forest ecosystems. Ecological Research 33, 149-160.

Fuji, K., Uemura, M., Hayakawa, C., Funakawa, S., Kosaki, T., 2013a. Environmental control of lignin peroxidase, manganese peroxidase, and laccase activities in forest floor layers in humid Asia. Soil Biology \& Biochemistry 57, 109-115.

Glenn, J.K., Gold, M.H., 1985. Purification and properties of an extracellular $\mathrm{Mn}$ (II)-dependent peroxidase from the lignin-degrading basidiomycete, Phanerochaete chrysosporium. Archives of Biochemistry and Biophysics 242, 329-341.

Gower, S.T., Vogel, J.G., Norman, J.M., Kucharik, C.J., Steele, S.J., Stow, T.K., 1997. Carbon distribution and aboveground net primary production in aspen, jack pine, and black spruce stands in Saskatchewan and Manitoba, Canada. Journal of Geophysical Research, D, Atmospheres 102, 29029-29041.

Hatakka, A., (2001) Biodegradation of lignin. In: Hofrichter, M., Steinbüchel, A., eds. Biopolymers: Biology, Chemistry, Biotechnology, Applications, vol 1. Lignin, Humic Substances and Coal. Wiley $\mathrm{VCH}$, Weinheim, pp. 129-180.

Hofrichter, M., 2002. Review: lignin conversion by manganese peroxidase (MnP). Enzyme and Microbial Technology 30, 454 466.

Inagaki, Y., Inagaki, M., Hashimoto, T., Kobayashi, M., Ito, Y., Shinomiya, Y., Yoshinaga, S., 2012. Aboveground production and nitrogen utilization in nitrogen-saturated coniferous plantation forests on the periphery of the Kanto Plain. Bull FFPRI 424, 161173.

Joergensen, R.G., Wichern, F., 2008. Quantitative assessment of the fungal contribution to microbial tissue in soil. Soil Biology \& Biochemistry 40, 2977-2991.

Kamei, I., Daikoku, C., Tsutsumi, Y., Kondo, R., 2008. Salinedependent regulation of manganese peroxidase genes in the hypersaline-tolerant white rot fungus Phlebia sp. strain MG-60. Applied and Environmental Microbiology 74, 2709-2716.

Kellner, H., Luis, P., Pecyna, M.J., Barbi, F., Kapturska, D., Krüger, D. Zak, D.R., Marmeisse, R., Vandenbol, M., Hofrichter, M., 2014. Widespread occurrence of expressed fungal secretory peroxidases in forest soils. PLoS One 9, e95557.
Kirk, T.K., 1984, Degradation of lignin. In: Gibson, D.T., ed. Microbial Degradation of Organic Compounds. Marcel Dekker, New York, pp, $399-437$.

Kirk, T.K., Farrell, R.L., 1987. Enzymatic "combustion": the microbial degradation of lignin. Annual Review of Microbiology 41, 465-505.

Leonowics, A., Cho, N.S., Luterek, J., Wilkolazka, A., WojtasWasilewska, M., Matuszewska, A., Hofrichter, M., Wesenberg, D., Rogalski, J., 2001. Fungal laccase: properties and activity on lignin. Journal of Basic Microbiology 41, 185-227.

Maisto, G., Baldantoni, D., De Marco, A., Alfani, A., Virzo De Santo, A., 2013. Ranges of nutrient concentrations in Quercus ilex leaves at natural and urban sites. Journal of Plant Nutrition and Soil Science 176, 801-808.

Meentemeyer, V., 1978. Macroclimate and lignin control of litter decomposition rates. Ecology 59, 465-472.

Megonigal, J.P., Conner, W.H., Kroeger, S., Sharitz, R.R., 1997. Aboveground production in southeastern floodplain forests: a test of the subsidy-stress hypothesis. Ecology 78, 370-384.

Mikan, C.J., Schimel, J.P., Doyle, A.P., 2002. Temperature controls of microbial respiration in arctic tundra soils above and below freezing. Soil Biology \& Biochemistry 34, 1785-1795.

Moore, T.R., Trofymow, J.A., Prescott, C.E., Fyles, J., Titus, B.D., 2006. Patterns of carbon, nitrogen and phosphorus dynamics in decomposing foliar litter in Canadian forests. Ecosystems (New York, N.Y.) 9, 46-62.

Morgenstern, I., Klopman, S., Hibbett, D.S., 2008. Molecular evolution and diversity of lignin degrading heme peroxidases in the Agaricomycetes. Journal of Molecular Evolution 66, 243-257.

Nakane, K., Kohno, T., Horikoshi, T., Nakatsubo, T., 1997. Soil carbon cycling at a black spruce (Picea mariana) forest stand in Saskatchewan, Canada. Journal of Geophysical Research, D, Atmospheres 102, 28785-28793.

Olson, J.S., 1963. Energy storage and the balance of producers and decomposers in ecological systems. Ecology 44, 322-331.

Orth, A.B., Royse, D.J., Tien, M., 1993. Ubiquity of lignin-degrading peroxidases among various wood-degrading fungi. Applied and Environmental Microbiology 59, 4017-4023.

Osono, T., 2007. Ecology of ligninolytic fungi associated with leaf litter decomposition. Ecological Research 22, 955-974.

Oyadomari, M., Shinohara, H., Johjima, T., Wariishi, H., Tanaka, H., 2003. Electrochemical characterization of lignin peroxidase from the white-rot basidiomycete Phanerochaete chrysosporium. Journal of Molecular Catalysis. B, Enzymatic 21, 291-297.

Rothschild, N., Levkowitz, A., Hadar, Y., Dosoretz, C.G., 1999. Manganese deficiency can replace high oxygen levels needed for lignin peroxidase formation by Phanerochaete chrysosporium. Applied and Environmental Microbiology 65, 483-488.

Rüttimann-Johnson, C., Cullen, D., Lamar, R.T., 1994. Manganese peroxidases of the white rot fungus Phanerochaete sordida. Applied and Environmental Microbiology 60, 599-605.

Shibata, M., Sugihara, S., Mvondo-Ze, A.D., Araki, S., Funakawa, S., 2017. Nitrogen flux patterns through Oxisols and Ultisols in tropical forests of Cameroon, Central Africa. Soil Science and Plant Nutrition 63, 306-317.

Sinsabaugh, R.L., 2010. Phenol oxidase, peroxidase and organic matter dynamics of soil. Soil Biology \& Biochemistry 42, 391-404. 
Slessarev, E.W., Lin, Y., Bingham, N.L., Johnson, J.E., Dai, Y., Schimel, J.P., Chadwick, O.A., 2016. Water balance creates a threshold in soil pH at the global scale. Nature 540, 567-569.

Šnajdr, J., Valášková, V., Merhautová, V., Herinková, J., Cajthaml, T., Baldrian, P., 2008. Spatial variability of enzyme activities and microbial biomass in the upper layers of Quercus petraea forest soil. Soil Biology \& Biochemistry 40, 2068-2075.

Staaf, H., 1987. Foliage litter turnover and earthworm populations in three beech forests of contrasting soil and vegetation types. Oecologia 72, 58-64.

Ten Have, R., Teunissen, P.J.M., 2001. Oxidative mechanisms involved in lignin degradation by white rot fungi. Chemical Reviews 101, 3397-3413.

Tien, M., Kirk, T.K., 1983. Lignin-degrading enzyme from the hymenomycete Phanerochaete chrysosporium Burds. Science $221,661-662$.

Trumbore, S., 2000. Age of soil organic matter and soil respiration: radiocarbon constraints on belowground $\mathrm{C}$ dynamics. Ecological Applications 10, 399-411.

Tuomela, M., Oivanen, P., Hatakka, A., 2002. Degradation of synthetic ${ }^{14} \mathrm{C}$-lignin by white-rot fungi in soil. Soil Biology \& Biochemistry 34 , 1613-1620.

Wong, D.W.S., 2009. Structure and action mechanism of ligninolytic enzymes. Applied Biochemistry and Biotechnology 157, 174209.

Yasuda, Y., Saito, T., Hoshino, D., Ono, K., Ohtani, Y., Mizoguchi, Y., Morisawa, T., 2012. Carbon balance in a cool-temperate deciduous forest in northern Japan: seasonal and interannual variations, and environmental controls of its annual balance. Journal of Forest Research 17, 253-267.

Yoshida, M., Hashimoto, K., lahimori, A., Nakada, Y., Hashimoto, K., Osaka, N., 2011. Detection of the genes encoding lignin and manganese peroxidases from white rot fungi. Wood Preservation $37,111-121$. 